
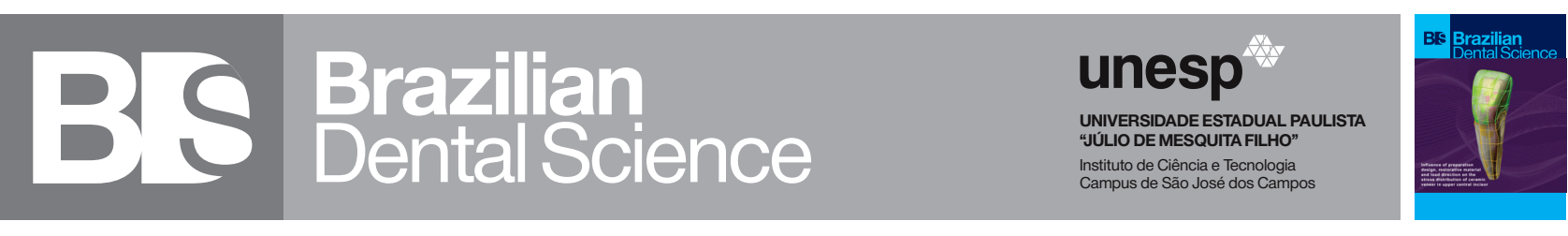

\title{
Biochemical and histopathological effects of diclofenac and ketoprofen administration on bone regeneration
}

Efeitos bioquímicos e histopatológicos da administração de diclofenaco e cetoprofeno na regeneração óssea

\author{
Victor CHUMPITAZ-CERRATE ${ }^{1,2}$, Lesly Karem Chávez RIMACHE ${ }^{1}$, Elías Ernesto Aguirre SIANCAS ${ }^{1}$, César Ivanovish Franco QUINO ${ }^{1,2}$, \\ Eliberto Ruiz RAMIREZ ${ }^{1,2}$, Carlos ERAZO-PAREDES ${ }^{1}$ \\ 1 - Research Group in Basic Stomatological Sciences (ICBEST), Universidad Nacional Mayor de San Marcos, Lima, Peru. \\ 2 - Pharmacology Laboratory, Faculty of Health Sciences, Universidad Científica del Sur, Lima, Peru.
}

\section{ABSTRACT}

Objective: To evaluate the biochemical and histopathological effects of diclofenac and ketoprofen administration on bone regeneration in a calvarial defect model in rats. Material and Methods: The sample consisted of 108 Wistar rats that were randomly distributed in three groups, to which an osteotomy of $6 \mathrm{~mm}$ in diameter was performed in the calvaria. Group A (control) was given saline solution; Group B received ketoprofen $2 \mathrm{mg} / \mathrm{kg}$ and Group C received diclofenac $2 \mathrm{mg} / \mathrm{kg}$. All treatments were administered intraperitoneally every 12 hours for 3 days. Bone regeneration was evaluated by biochemical (alkaline phosphatase and serum calcium) and histopathological (osteocyte and osteoblast cell count) characteristics at 15 and 30 days. Results: In the biochemical evaluation, alkaline phosphatase levels in the ketoprofen group were significantly lower compared to the diclofenac group at 15 and 30 days $(\mathrm{p}=0.015$ and $\mathrm{p}=0.001$; respectively). However, serum calcium levels did not show the difference between the study groups at 15 and 30 days $(\mathrm{p}=0.42$ and $\mathrm{p}=0.81$; respectively). In the histopathological analysis, the count of osteoblasts and osteocytes was significantly lower in the ketoprofen group compared to the diclofenac group at 15 and 30 days $(\mathrm{p}<0.05)$. Conclusion: The administration of ketoprofen has negative biochemical and histopathological effects of greater intensity on bone regeneration compared to the administration of diclofenac.

\section{KEYWORDS}

Bone regeneration; Nnon-steroidal antiinflammatory agents; Diclofenac; Ketoprofen; Rats.

\section{RESUIMO}

Objetivo: Avaliar os efeitos bioquímicos e histopatológicos da administração de diclofenaco e cetoprofenonaregeneraçãoóssea emmodelodedefeito calvarial em ratos. Material e Métodos: A amostra foi composta por 108 ratos Wistar que foram distribuídos aleatoriamente em três grupos, aos quais foi realizada osteotomia de $6 \mathrm{~mm}$ de diâmetro na calvária. $\mathrm{O}$ grupo A (controle) recebeu solução salina; O Grupo B recebeu $2 \mathrm{mg} / \mathrm{kg}$ de cetoprofeno e o Grupo C recebeu $2 \mathrm{mg} / \mathrm{kg}$ de diclofenaco. Todos os tratamentos foram administrados intraperitonealmente a cada 12 horas durante 3 dias. A regeneração óssea foi avaliada pelas características bioquímicas (fosfatase alcalina e cálcio sérico) e histopatológicas (contagem de osteócitos e células de osteoblastos) aos 15 e 30 dias. Resultados: Na avaliação bioquímica, os níveis de fosfatase alcalina no grupo cetoprofeno foram significativamente menores em comparação com o grupo diclofenaco em 15 e 30 dias ( $p=0.015$ e $p=0.001$; respectivamente). No entanto, os níveis séricos de cálcio não mostraram diferença entre os grupos de estudo aos 15 e 30 dias $(\mathrm{p}=0.42 \mathrm{p}=0.81$; respectivamente $) \mathrm{Na}$ análise histopatológica, a contagem de osteoblastos e osteócitos foi significativamente menor no grupo cetoprofeno em comparação ao grupo diclofenaco aos 15 e 30 dias $(p<0,05)$. Conclusão: A administração de cetoprofeno tem efeitos bioquímicos e histopatológicos negativos de maior intensidade na regeneração óssea em comparação com a administração de diclofenaco.

\section{PALAVRAS-CHAVE}

Regeneração óssea; Anti-Inflamatórios não esteroides; Diclofenaco; Cetoprofeno; Ratos. 


\section{INTRODUCTION}

$\mathrm{N}$ on-steroidal anti-inflammatory drugs (NSAIDs) are widely prescribed for the management of pain and inflammation in the postoperative period [1].

Bone regeneration is a dynamic process where the immune system and the skeletal system interact, in which inflammatory mediators such as prostaglandin E2 and insulin-like growth factor (IGF) intervene, which modulate the function and formation of osteocytes, osteoblasts and osteoclasts. In addition, it stimulates the synthesis of collagen [3-5].

NSAIDs act by inhibiting the synthesis of the cyclooxygenase (COX) enzyme and its metabolites, such as prostaglandin E2 [6,7]. Prostaglandins can promote bone regeneration, promoting angiogenesis and stimulating the activity of osteoblasts and osteoclasts. For this reason, NSAIDs could be harmful agents for bone regeneration [8-11].

Studies have evaluated the effect of NSAIDs on fracture healing by causing deterioration of osteoblast proliferation in the initial stages of the regeneration process; nonetheless, there are no conclusive results because there is a lot of heterogeneity in the designs, doses, treatment periods and use of different experimental animals [12-14].

Two of the most prescribed NSAIDs in patients undergoing surgical procedures with bone tissue manipulation in dentistry are diclofenac and ketoprofen. The knowledge of the effect of these NSAIDs on bone tissue regeneration is important for decision making in clinical practice; Preclinical models with methodologically appropriate designs are a preliminary step to clinical research. For this reason, the objective of the study was to evaluate the biochemical and histopathological effects of the administration of diclofenac and ketoprofen on bone regeneration in a calvarial defect model in rats.

\section{MATERIALS AND METHODS}

\section{Ethical considerations}

The recommendations provided of the ARRIVE guidelines and the guideline of the National Institutes of Health for the care and use of laboratory animals were followed [15]. In vivo experimental preclinical study was approved by the research institute of the Faculty of Dentistry of the National University of San Marcos.

The sample consisted of 108 ten-week-old male Wistar albino rats with an average weight of $300 \pm 20 \mathrm{~g}$, obtained from the Bioterium of the Cayetano Heredia University (UPCH), Lima-Peru.

The rats were conditioned and acclimated for 7 days with a temperature of $21 \pm 5{ }^{\circ} \mathrm{C}$, ad libitum feeding and light/dark cycles of 12 hours in the Bioterium of the Faculty of Medicine of the National University of San Marcos (UNMSM).

\section{bone defects}

Treatment protocol and formation of

All 108 rats underwent general anesthesia with Ketamine (Ketalar ${ }^{\circledR}$ ) $100 \mathrm{mg} / \mathrm{kg}$ and Xylazine (Dormi-Xyl ${ }^{\circledR}$ ) $10 \mathrm{mg} / \mathrm{kg}$, administered by IP. Then the parietal region was depilated and the asepsis and antisepsis measures were applied (Yodopovidone 10\% + Active Iodine $1 \%)$. Subsequently, a linear incision was made with a No. 15 scalpel blade, taking the sagittal suture as a reference, and the bone surface of the calvaria was exposed. Next, the circular osteotomy was performed with a trephine drill (6 mm $\varnothing$ - Neodent ${ }^{\circledR}$ ) with abundant saline irrigation (the drill was coupled to a low speed micromotor, BLM 600 Plus Motor - Driller $\left.^{\circledR}\right)$. Subsequently, the bone fragment $(6 \mathrm{~mm}$ in diameter) was carefully removed with the help of a surgical chisel. Subsequently, the blood clot was allowed to form and the edges of the wound were subsequently faced with isolated stitches (Vycril ${ }^{\circledR}$ 4/0 MR 20).5 [16].

The 108 rats were randomly and equitably distributed into three groups of 36 rats each one (A, B, and C): Group A (control) was administered saline solution $2 \mathrm{mg} / \mathrm{kg}$; to group B, ketoprofen $2 \mathrm{mg} / \mathrm{kg}$ and to group C, diclofenac $2 \mathrm{mg} / \mathrm{kg}$. All 
treatments were administered intraperitoneally every 12 hours for three days. The administration of the treatments began immediately after the bone defects had been made.

\section{Biochemical Evaluation}

For the biochemical and histopathological evaluation, 12 rats from each group were randomly selected at 0,15 and 30 days after having performed the bone defects, which were euthanized by an overdose of pentobarbital 1 $\mathrm{mL} / 250 \mathrm{~g}$ via IP $\left(\right.$ HALATAL $\left.^{\circledR}\right)$.

For biochemical evaluation, $5 \mathrm{~mL}$ of blood was drawn from the heart to evaluate osteogenesis markers such as alkaline phosphatase and serum calcium.

\section{Histopathological Evaluation}

For histopathological evaluation, samples were taken from the cranial vault and dissected within $5 \mathrm{~mm}$ of the surgically operated region. Samples were fixed in 10\% phosphate-buffered saline over 24 hours. Subsequently, it was decalcified with 14.5\% ethylenediaminetetraacetic acid at room temperature for a period of 5 to 6 weeks. The samples were dehydrated with ethanol and then included in paraffin.

Slices were made in $5 \mathrm{~mm}$ sections with a microtome (Kedee KD-2258) for subsequent staining with hematoxylin and eosin.

A light microscope (Micros MCX100 LCD Crocus II) was used to take the digital images of the histological sections.

A specialist in pathology, who didn't know the subgroups of the plates, performed the cell count of osteoblasts and osteocytes to evaluate bone regeneration in the intervened area. Because the bone regeneration process had not yet begun on day 0 , the cell count was only performed at 15 and 30 days. To carry out the cell count, the intervened area was identified through microscopy, 4 fields of this area were taken at random, and then the cell count of osteoblasts and osteocytes was performed in an hourly manner.

An average of the four observations was taken, which was the final number of osteocytes and osteoblasts. Each observed microscopic area was $0.458 \mathrm{~mm}^{2}$ with a total magnification of 400X.

\section{Statistical analysis}

For the data analysis, the statistical package STATA v16.0 version was used. Biochemical and histopathological analyzes showed a normal distribution. For this reason, the statistical ANOVA test and post hoc were used to compare the study groups (control, diclofenac and ketoprofen). A confidence level of $95 \%$ and a value of $p<0.05$ were taken into account to consider a statistically significant difference. All cell count data is shown as median \pm standard deviation.

\section{RESULTS}

\section{Biochemical evaluation}

\section{Alkaline phosphatase}

In the alkaline phosphatase evaluation on day 0 , no significant differences were found between the study groups $(p=1.21)$. At 15 days, the alkaline phosphatase level in the diclofenac group was $161.8 \pm 20.13$ (95\% CI 153.31-170.32) and in the ketoprofen group it was $142.6 \pm 14.02$ (95\% CI 136.71-148.55). At 30 days, the alkaline phosphatase level in the diclofenac group was $197.89 \pm 14.47$ (95\% CI 191.77-204.01) and in the ketoprofen group it was $165.19 \pm 10.26$ (95\% CI 160.85-169.52). According to the statistical analysis of ANOVA, significant differences were found between the study groups at 15 and 30 days $(\mathrm{p}=0.015$ and $\mathrm{p}=0.001$; respectively) (Table I). When post-hoc was applied, it was determined that there were significant differences between all study groups at 15 and 30 days $(\mathrm{p}<0.05)$. 
Table I - Alkaline phosphatase levels in the study groups at 15 and 30 days

\begin{tabular}{|c|c|c|c|c|c|}
\hline & \multicolumn{5}{|c|}{ Alkaline phosphatase } \\
\hline & Day 0 & & Day 15 & & Day 30 \\
\hline & Mean $\pm D S$ & $p^{*}$ & Mean $\pm D S$ & $p^{*}$ & Mean $\pm D S \quad p^{*}$ \\
\hline Control & $139.66 \pm 16.80$ & 1.21 & $188.9 \pm 17.38$ & 0.015 & $217.09 \pm 15.090 .001$ \\
\hline Diclofenac & $139.66 \pm 26.28$ & & $161.8 \pm 20.13$ & & $197.89 \pm 14.47$ \\
\hline Ketoprofen & $136.66 \pm 26.88$ & & $142.6 \pm 14.02$ & & $165.19 \pm 10.26$ \\
\hline
\end{tabular}

$X \pm$ SD: Mean and Standard Deviation *ANOVA test; $p<0.05$. a: Dunn-Bonferroni test $(p<0.05$ with reference to the control group).

\section{Serum calcium}

In the evaluation of the serum calcium level, no significant difference was found at 15 or 30 days between all study groups $(\mathrm{p}=0.42$ and $\mathrm{p}=0.81$, respectively) (Table II).

Table II - Serum calcium levels in the study groups at 15 and 30 days

\begin{tabular}{c|cccccc} 
& \multicolumn{5}{c}{ Serum calcium levels } \\
& Day 0 & \multicolumn{2}{c}{ Day 15 } & Day 30 \\
& Mean \pm DS & $\boldsymbol{p}$ & Mean \pm DS & $\boldsymbol{p}$ & Mean \pm DS & $\boldsymbol{p}^{*}$ \\
\hline Control & $8.65 \pm 0.76$ & 1.00 & $9.15 \pm 0.6$ & 0.42 & $8.54 \pm 0.94$ & 0.81 \\
Diclofenac & $8.65 \pm 0.76$ & $8.95 \pm 0.89$ & $8.46 \pm 1.12$ & \\
\hline Ketoprofen & $8.65 \pm 0.76$ & $8.83 \pm 1.05$ & $8.38 \pm 0.48$ &
\end{tabular}

$X \pm$ SD: Mean and Standard Deviation *ANOVA test; $p<0.05$. a: Dunn-Bonferroni test $(p<0.05$ with reference to the control group).

\section{Histopathological Evaluation}

\section{Osteoblast count at $\mathbf{1 5}$ and $\mathbf{3 0}$ days}

No difference in osteoblast count was found on day 0 between study groups. At 15 days, the ketoprofen group (23.66 \pm 4.52 [95\% CI 21.74-25.59]) presented the lowest number of osteoblasts compared to diclofenac (30.25 \pm 3.46 [95\% CI 28.78-31.71]) $(\mathrm{p}=0.01)$. Similarly, at 30 days, the ketoprofen group (34.66 \pm 4.07 [95\% CI 32.94-36.38]) presented fewer osteoblasts compared to diclofenac $(41.41 \pm 4.79$ [95\% CI 39.3-43.4]) $(\mathrm{p}=0.001)$ (Table III).
When post-hoc was applied, it was determined that there were significant differences between all study groups at 15 and 30 days $(\mathrm{p}<$ 0.05).

Table III - Cell count of osteoblasts in study groups at 15 and 30 days

\begin{tabular}{|ccccccc} 
& \multicolumn{4}{c}{ Osteoblasts } \\
& Day 0 & Day 15 & Day 30 \\
\hline & Mean \pm DS & $\boldsymbol{p}$ & Mean \pm DS & $\boldsymbol{p}$ & Mean \pm DS & $\boldsymbol{p}^{*}$ \\
\hline Control & $17.96 \pm 2.8$ & 1.19 & $35.16 \pm 5.35$ & 0.01 & $53.66 \pm 5.23$ & 0.001 \\
\hline Diclofenac & $17.12 \pm 4.12$ & $30.25 \pm 3.46$ & $41.41 \pm 4.79$ & \\
\hline Ketoprofen & $16.78 \pm 2.68$ & $23.66 \pm 4.52$ & & $34.66 \pm 4.07$
\end{tabular}

$X \pm$ SD: Mean and Standard Deviation *ANOVA test; $p<0.05$. a: Dunn-Bonferroni test ( $p<0.05$ with reference to the control group).

\section{Osteocyte count at $\mathbf{1 5}$ and $\mathbf{3 0}$ days}

No difference in osteocyte count was found on day 0 between study groups. Nevertheless, at 15 days the ketoprofen group (18.91 \pm 3.85 [95\% CI 17.28-20.54]) presented the lowest number of osteocytes compared to diclofenac $(25.66 \pm 3.39$ [95\% CI 24.23-27.10]) $(\mathrm{p}=0.015)$. Similarly, at 30 days, the ketoprofen group $(29.33 \pm 3.37$ [95\% CI 27.91-30.75]) had a lower number of osteocytes compared to diclofenac $(35.83 \pm 3.86$ [95\% CI 34.19-37.47]) $(\mathrm{p}=0.001)$ (Table IV).

Applying post-hoc, it was determined that there are specific differences between all study groups at 15 and 30 days $(\mathrm{p}<0.05)$.

Table IV - Cell count of osteocytes in the study groups at 15 and 30 days

\begin{tabular}{|c|c|c|c|c|c|c|}
\hline & \multicolumn{6}{|c|}{ Osteocytes } \\
\hline & \multicolumn{2}{|l|}{ Day 0} & \multicolumn{2}{|c|}{ Day 15} & \multicolumn{2}{|l|}{ Day 30} \\
\hline & Mean $\pm D S$ & $p$ & Mean $\pm D S$ & $p$ & Mean $\pm \mathrm{DS}$ & $p^{\star}$ \\
\hline Control & $16.56 \pm 2.12$ & 1.21 & $29.58 \pm 3.71$ & 0.018 & $48.08 \pm 5.78$ & 0.001 \\
\hline Diclofenac & $17.89 \pm 2.34$ & & $25.66 \pm 3.39$ & & $35.83 \pm 3.86$ & \\
\hline Ketoprofen & $15.29 \pm 3.88$ & & $18.91 \pm 3.85$ & & $29.33 \pm 3.37$ & \\
\hline
\end{tabular}

$X \pm$ SD: Mean and Standard Deviation *ANOVA test; $p<0.05$. a: Dunn-Bonferroni test ( $p<0.05$ with reference to the control group). 
In the histopathological analysis, the osteoblast and osteocyte count showed that the administration of diclofenac and ketoprofen decreased the cell count at 15 and 30 days compared to the control group (Figure 1).

At 15 days it was observed that there were a greater number of osteoblasts and osteocytes in the diclofenac group (Figure 1C) compared to the ketoprofen group (Figure 1B). Similarly, at 30 days a significant difference in cell count was demonstrated between the diclofenac group (Figure 1F) and the ketoprofen group (Figure 1E).



Table IV - Histopathological evaluation. Micrographs of representative areas of each experimental group are observed at magnifications of $400 x$ and colored with $\mathrm{H}-\mathrm{E}$. (1) osteoblasts, (2) osteocytes. 1A. Control group at 15 days. Abundant number of osteoblasts with an incipient formation of trabeculae are observed. 1B. Ketoprofen group at 15 days. A small number of osteoblasts in formation with an incipient trabecular area is observed.1C. Diclofenac group at 15 days. Osteoblasts are seen around the forming trabeculae. 1D. Control group at 30 days. Abundant osteocytes are observed within the already formed trabeculae. 1E. Ketoprofen group at 30 days. Few osteocytes are seen within the trabeculae as well as few osteoblasts around them. 1F. Diclofenac group at 30 days. Trabecular areas with osteoblasts and osteocytes are observed.

\section{DISCUSSION}

In the present investigation, it was found that the administration of diclofenac and ketoprofen had negative biochemical and histopathological effects on bone regeneration compared to the control group. Specifically, the ketoprofen group presented higher intensity biochemical and histopathological effects on bone regeneration compared to the diclofenac group.

Alkaline phosphatase is an osteoblastic differentiation marker, whose transcription of its gene is dependent on the RUNX2 pathway, one of the main genes involved in osteogenesis.

Our study showed that ketoprofen was the one that reduced the levels of alkaline phosphatase the most at 15 and 30 days compared to diclofenac $(p=0.015$ and $p=0.001$, respectively). Similarly, Melguizo-Rodríguez et al. [17] carried out a study to determine the effect of paracetamol, indomethacin, ketoprofen, diclofenac, ibuprofen, ketorolac, naproxen and piroxicam on three lines of human osteoblasts from bone samples, finding that ketoprofen and diclofenac decreased RUNX2 and alkaline phosphatase expression compared to control. Even though the study by MelguizoRodríguez et al. [17] was in vitro compared to our study, the cellular behavior is similar from the metabolic and biochemical point of view. On the other hand, Manzano-Moreno et al. [18] carried out a study that evaluated the effects of NSAIDs on the expression of vascular endothelial growth factor (VEGF) in two osteoblast cell lines, finding that paracetamol, indomethacin, ketoprofen, diclofenac, ibuprofen, ketorolac, naproxen or piroxicam significantly reduced VEGF expression independently of the cell line (primary culture osteoblasts and human osteosarcoma cell line MG63); Furthermore, they mentioned that more studies are needed to elucidate the signaling mechanism by which NSAIDs appear to have undesired effects on osteoblasts.

In the histopathological evaluation in our study, it was found that the osteocytes and osteoblasts were significantly reduced in the groups that received treatment with diclofenac and with ketoprofen, being the negative effect of greater magnitude with ketoprofen. These findings were similar to those reported by Inal et al. [19] who evaluated the fibular fracture model in rats and after 10 days of the administration of various NSAIDs, performed a cell count in the 
bone marrow of the area where the bone callus was formed. They found that the administration of dexketoprofen $(0.98 \mathrm{mg} / \mathrm{Kg})$ produced a lower cell count $(74.28 \pm 18.12)$ compared to the administration of diclofenac $(1 \mathrm{mg} / \mathrm{Kg}$ ) that showed a cell count $(92.85 \pm 4,87)$ very similar to that of the control group (91.42 \pm 8.99). In addition, in the histopathological analysis with the scale of Huo et al. [20] (categorical scale from " 1 to 10 ", in which " 1 " is only fibrous tissue formation and " 10 " is a healing of the fracture with mature bone tissue) it was found that diclofenac $(7.85 \pm 0.37)$ did not affect the bone healing process compared to the control group (7.85 \pm 0.36). However, dexketoprofen (7.14 \pm 0.69) presented less bone healing compared to the control group $(7.85 \pm 0.36) ; \mathrm{p}=0.033$.

On the other hand, Krischak et al. [21], found that diclofenac negatively affected osteoblasts by inhibiting their function, this was evidenced by a lower osteoblast count and reduced bone mineral density in rats. This study found that the administration of diclofenac ( $5 \mathrm{mg}$ $/ \mathrm{kg}$ ) for 10 days had a lower osteoblast count (73.5 \pm 8.4 cells / grid) compared to the placebo group (111.5 \pm 89.3 cells / grid); $p=0.001$.

Xie et al. [13] found that acetylsalicylic acid at low doses $(<100 \mathrm{ug} / \mathrm{mL})$, administered for 3-7 days, inhibits osteoclastic function, being beneficial for the treatment of osteoporosis. However, acetylsalicylic acid at high doses (150-300 $\mu \mathrm{g} / \mathrm{mL}$ ) inhibits osteoblastic function, producing a negative effect on bone tissue. Therefore, it could be inferred that, with the administration of low doses of acetylsalicylic acid, the healing process and the bone remodeling process would not be delayed because only the enzyme cyclooxygenase-1 (COX-1) is inhibited.

Regarding the selective inhibitors of the enzyme cyclooxygenase-2 (COX-2), Simon et al. [22] evaluated the effects of the administration of celecoxib (4-8 mg/Kg) for 15 days in a model of femoral fracture in rats. Eight weeks after the fracture, a significant reduction in the mechanical properties of the bone callus was observed and a significant increase in the proportion of non- union of the fracture, $(\mathrm{p}<0.001)$. This possibly due to the fact that the COX-2 enzyme plays an important role in the bone regeneration process.

Zhang et al. [23] found that mice lacking the functional COX-2 gene exhibited delayed healing of the stabilized tibia fracture at 14 and 21 days. Histopathological analysis revealed undifferentiated mesenchymal tissue and a reduction in osteoblastogenesis in the area of the fracture junction.

On the other hand, in a systematic review executed by Borgeat et al. [24] they found preclinical and clinical studies, in which there was no conclusive evidence of the effect of NSAIDs, administered after osteosynthesis of a spinal fracture or fusion, on the consolidation process. However, they report that there is much heterogeneity in the studies (different experimental models and different treatment durations) to make a judgment on the use of NSAIDs in bone regeneration. Similarly, Duchman et al. [25] conducted a systematic review with meta-analysis on the effect of NSAIDs administered for 10-42 days on tendonto-bone healing after acute injury or surgery, including basic and clinical studies. They performed a homogeneous subgroup analysis between selective NSAIDs (SMD: -1.05 [95\% CI -2.38 to 0.30$]$ ) and non-selective NSAIDs (SMD: -0.62 [95\% CI -1.26 to 0.02]); however, they did not find significant differences $(p=0.13)$. They state that the evaluated studies are of low methodological quality, so a judgment cannot be made in favor or against the use of NSAIDs.

It is recommended to carry out studies with other NSAIDs that have a different affinity to inhibit the enzyme cyclooxygenase (for example, selective COX-2 inhibitors such as parecoxib or etoricoxib), to evaluate if some of these NSAIDs have negative effects on the bone regeneration process. Furthermore, it is recommended to carry out studies with agents that promote bone regeneration, such as the mineral trioxide aggregate (MTA), to evaluate the extent to which these agents could antagonize the negative effects of NSAIDs on bone regeneration. 


\section{CONCLUSION}

The administration of diclofenac and ketoprofen have negative biochemical and histopathological effects on bone regeneration compared to the control group. The administration of ketoprofen has greater negative biochemical and histopathological effects on bone regeneration compared to the administration of diclofenac.

\section{Funding Source}

\section{Subsidized A17052091 (RAIS UNMSM)}

\section{Acknowledgment}

Our gratitude to the National University of San Marcos (UNMSM) for providing us with financial support to carry out this research work.

\section{Conflicts of interest}

There is no type of financial and nonfinancial conflicts of interest from the authors.

\section{REFERENCES}

1. Etikala A, Tattan M, Askar H, Wang HL. Effects of NSAIDs on periodontal and dental Implant therapy. Compend Contin Educ Dent. 2019;40(2):e1-e9.

2. Zimmerman SM, Heard-Lipsmeyer ME, Dimori M, Thostenson JD, Mannen EM, O'Brien CA, et al. Loss of RANKL in osteocytes dramatically increases cancellous bone mass in the osteogenesis imperfecta mouse (oim). Bone Rep. 2018;9:61-73. doi: 10.1016/j.bonr.2018.06.008

3. Giannoudis PV, Hak D, Sanders D, Donohoe E, Tosounidis T, Bahney C. Inflammation, bone healing, and anti-inflammatory drugs: an update. J Orthop Trauma. 2015;29 Suppl 12:S6-9. doi: 10.1097/ BOT.0000000000000465.

4. Sauerschnig M, Stolberg-Stolberg J, Schmidt C, Wienerroither V, Plecko M, Schlichting K, et al. Effect of COX-2 inhibition on tendon-to-bone healing and PGE2 concentration after anterior cruciate ligament reconstruction. Eur J Med Res. 2018;23(1):1. doi: 10.1186/s40001-017-0297-2

5. Oliveira MR, de CSA, Ferreira S, Avelino CC, Garcia IR Jr, Mariano RC. Influence of the association between platelet-rich fibrin and bovine bone on bone regeneration: a histomorphometric study in the calvaria of rats. Int $\mathrm{J}$ Oral Maxilofac Surg. 2015;44(5):649-55.

6. Gomes FIF, Aragão MGB, Pinto VPT, Gondim DV, Barroso FC, Silva AAR, et al. Effects of nonsteroidal anti-inflammatory drugs on osseointegration: a review. J Oral Implantol. 2015;41(2):219-30.

7. Bissinger 0 , Kreutzer K, Gotz C, Hapfelmeier A, Pautke C, Vogt S, et al. A biomechanical, micro-computertomographic and histological analysis of the influence of diclofenac and prednisolone on fracture healing in vivo. BMC MusculoskeletDisord. 2016;17(1):383.
8. Cai WX, Ma L, Zheng LW, Kruse-Gujer A, Stubinger S, Lang NP, et al. Influence of non-steroidal anti-inflammatory drugs (NSAIDs) on osseointegration of dental implants in rabbit calvaria. Clin Oral Implants Res. 2015;26(4):478-83.

9. Liu Y, Fang S, LiX, Feng J, Du J, Guo L, etal. Aspirin inhibits LPS-induced macrophage activation via the NF-kappaB pathway. Sci Rep. 2017;7(1):11549.

10. Luo JD, Miller C, Jirjis T, Nasir M, Sharma D. The effect of non-steroidal anti-inflammatory drugs on the osteogenic activity in osseointegration: a systematic review. Int J Implant Dent. 2018;4(1):30.

11. Garcia-Martinez 0, Luna-Bertos E, Ramos-Torrecillas J, Manzano-Moreno FJ, Ruiz C. Repercussions of NSAIDS drugs on bone tissue: the osteoblast. Life Sci. 2015;123:72-7.

12. WinnettB, Tenenbaum HC, Ganss B, Jokstad A. Perioperative use of non-steroidal anti-inflammatory drugs might impair dental implant osseointegration. Clin Oral Implants Res. 2016;27(2):e1-7.

13. Xie Y,Pan M, Gao Y,Zhang L, Ge W, Tang P.Dose-dependent roles of aspirin and other non-steroidal anti-inflammatory drugs in abnormal bone remodeling and skeletal regeneration. Cell Biosci. 2019;9:103.

14. Salduz A, Dikici F, Kilicoglu Ol, Balci H, Akgul T, Kurkcu M, et al. Effects of NSAIDs and hydroxyapatite coating on osseointegration. J Orthop Surg . 2017;25(1):23-9. doi:10.1177/2309499016684410.

15. National Research Council (US) Committee for the Update of the Guide for the Care and Use of Laboratory Animals [Internet]. 8th ed. Washington (DC): National Academies Press (US); 2011 [cited 2020 May 8]. (The National Academies Collection: Reports funded by National Institutes of Health). Available from: http://www.ncbi.nIm.nih.gov/books/NBK54050/

16. Messora MR, Nagata MJ, Dornelles RC, Bomfim SR, Furlaneto FA, Melo $L G$, et al. Bone healing in critical-size defects treated with platelet-rich plasma: a histologic and histometric study in rat calvaria. J Periodontal Res. 2008;43(2):217-23.

17. Melguizo-Rodríguez L, Costela-Ruiz VJ, Manzano-Moreno FJ, IllescasMontes R, Ramos-Torrecillas J, García-Martínez 0, et al. Repercussion of nonsteroidal anti-inflammatory drugs on the gene expression of human osteoblasts. PeerJ.2018;6:e5415-e5415.

18. Manzano-Moreno FJ, Costela-Ruiz VJ, Melguizo-Rodriguez L, IllescasMontes R, Garcia-Martinez 0, Ruiz C, et al. Inhibition of VEGF gene expression in osteoblast cells by different NSAIDs. Arch Oral Biol. 2018;92:75-8.

19. Inal S, Kabay S, Cayci MK, Kuru Hl, Altikat S, Akkas G, et al. Comparison of the effects of dexketoprofen trometamol, meloxicam and diclofenac sodium on fibular fracture healing, kidney and liver: an experimental rat model. Injury. 2014;45(3):494-500

20. Huo MH, Troiano NW, Pelker RR, Gundberg CM, Friedlaender GE. The influence of ibuprofen on fracture repair: biomechanical, biochemical, histologic, and histomorphometric parameters in rats. J Orthop Res. 1991;9(3):383-90

21. Krischak GD, AugatP, Blakytny R, Claes L, KinzI L, Beck A. The non-steroidal anti-inflammatory drug diclofenac reduces appearance of osteoblasts in bone defect healing in rats. Arch Orthop Trauma Surg. 2007;127(6):453-8.

22. Simon AM, O'Connor JP. Dose and time-dependent effects of cyclooxygenase-2 inhibition on fracture-healing. J Bone Joint Surg Am. 2007;89(3):500-11.

23. Zhang X, SchwarzEM, Young DA, Puzas JE, Rosier RN, O'Keefe RJ. Cyclooxygenase-2 regulates mesenchymal cell differentiation into the osteoblast lineage and is critically involved in bone repair. J Clin Invest. 2002;109(11):1405-15. 
24. Borgeat A, Ofner C, Saporito A, Farshad M, Aguirre J. The effect of nonsteroidal anti-inflammatory drugs on bone healing in humans: $A$ qualitative, systematic review. J Clin Anesth. 2018;49:92-100.
25. Duchman KR, Lemmex DB, Patel SH, Ledbetter L Garrigues GE, Riboh JC The effect of non-steroidal anti-inflammatory drugs on tendon-to-bone healing: a systematic review with subgroup meta-analysis. lowa Orthop J. 2019;39(1):107-19.

\section{Victor Chumpitaz-Cerrate}

(Corresponding address)

Research Group in Basic Stomatological Sciences (ICBEST), Universidad Nacional

Mayor de San Marcos, Lima, Peru.

Pharmacology Laboratory, Faculty of Health Sciences, Universidad Científica del Sur,

Lima, Peru. Germán Amézaga Nro. 375 - Lima, Perú.

Date submitted: 2020 Sep 05

Email: vchumpitazc@unmsm.edu.pe 